\title{
Analysis of Mathematical Representation Ability Based on Level of Reading Interest in Geometry Course
}

\author{
Destia Wahyu Hidayati ${ }^{*}$, Arie Wahyuni ${ }^{2}$ \\ ${ }^{1,2}$ Universitas Ivet \\ *destia281289@gmail.com
}

Received: May 2021. Accepted: June 2021. Published: July 2021.

\begin{abstract}
Reading literacy activities are currently being held by all levels of education. Literacy activities have a positive effect on students in understanding information. The ability to understand information can be realized through mathematical representation, which is one of the main elements in mathematical understanding. This research can help educators in mapping the mathematical representation ability based on the reading interest of students. The purpose of this research is to identify which indicators can be mastered by students who have reading interests at high, medium, and low levels. This research is qualitative. The research subjects were students of the Mathematics Education Department of Ivet University. The data collection procedures used were scale, test, and interview. The instruments of this study were the reading interest scale, mathematical representation ability test, and interview sheets. The data analysis technique of this study adopted data analysis techniques from Miles and Huberman. The conclusions of this study are (1) students with high and medium reading levels have the ability to represent mathematical representations to model and interpret physical, social, and mathematical phenomena; have the ability of mathematical representations to create and use representations to communicate mathematical ideas or concepts; have the ability of mathematical representations in selecting, applying, and translating mathematical representations to solve problems, (2) students with a low reading level have lacked on the ability of mathematical representations to use representations to model and interpret physical, social, and mathematical phenomena, thus it caused them couldn't mastering the ability of mathematical representations to create and use representations to communicate mathematical ideas or concepts and the ability of mathematical representations to select, apply, and translate mathematical representations to solve problems.
\end{abstract}

Keywords: mathematical representation ability, reading interest, geometry.

How to Cite: Hidayati, D. W. \& Wahyuni, A. (2021). Analysis of Mathematical Representation Ability Based on Level of Reading Interest in Geometry Course. Journal of Medives: Journal of Mathematics Education IKIP Veteran Semarang, 5(2), 271-279. 


\section{PENDAHULUAN}

Pemahaman matematis sering digunakan dalam menyelesaikan persoalan dalam kehidupan sehari-hari. Pemahaman matematis tidak hanya terwujud dalam nilai ulangan matematika, tetapi bisa juga diwujudkan pada kemampuan yang lain. Dalam pembelajaran matematika, peserta didik pasti akan melakukan representasi. Representasi adalah bentuk interpretasi dari pemikiran siswa dalam menghadapi masalah, dan digunakan sebagai alat bantu untuk memecahkan masalah tersebut (Sabirin, 2014). Representasi merupakan keterampilan yang harus dipunyai peserta didik untuk menguasai pembelajaran matematika (Mainali, 2021). Kemampuan representasi merupakan salah satu standar yang dapat mendeskripsikan pemahaman matematis (NCTM, 2000). Kemampuan representasi yang dimiliki peserta didik juga berguna untuk memecahkan permasalahan dalam kehidupan sehari-hari (Widakdo, 2017). Kemampuan dalam memahami matematika dapat dilihat dari hasil kemampuan representasi (Wilkinson, Bailey, \& Maher, 2018). Kemampuan representasi matematis adalah kemampuan peserta didik dalam mengungkapkan ide matematika yang dapat digunakan dalam memecahkan suatu masalah (Rahmadian, Mulyono, \& Isnarto, 2019). Indikator kemampuan representasi matematis ada tiga buah yaitu: (1) menggunakan menggunakan representasi (verbal, simbolik dan visual) untuk memodelkan dan menafsirkan fenomena fisik, sosial, dan matematika; (2) membuat dan menggunakan representasi (verbal, simbolik dan visual) untuk mengatur, mengkomunikasikan ide-ide matematika; (3) memilih, menerapkan, dan menerjemahkan representasi (verbal, simbolik dan visual) matematika untuk memecahkan masalah (Graciella \& Suwangsih, 2016). Kemampuan representasi matematis merupakan kemampuan dasar untuk mengembangkan kemampuan berpikir peserta didik (Yuniawatika, 2011). Kemampuan representasi matematis yang dimiliki oleh peserta didik dapat menjadikannya mengonkretkan gagasan-gagasan yang dimiliki, atau sebaliknya bahwa representasi matematis yaitu pemodelan dari dunia nyata pada bentuk yang abstrak (Miladiah, Nurhaida, \& Karimah, 2020; Rahmadian et al., 2019). Dengan mempunyai kemampuan representasi matematis, peserta didik mampu mentransformasikan informasi dalam bentuk tabel, diagram, dan gambar. Selain dapat mentransformasikan informasi, peserta juga dapat menggunakan hasil transformasi tersebut dalam sebuah proses untuk memecahkan permasalahan. Proses dalam memecahkan masalah juga diawali dengan membaca dari permasalahan, baik permasalahan di dalam kehidupan seharihari maupun permasalahan di dalam pembelajaran di jenjang pendidikan.

Untuk saat ini, kegiatan literasi juga digalakkan pada setiap jenjang pendidikan. Di awal pembelajaran, peserta didik diminta untuk membaca bacaan bebas, bisa buku fiksi maupun nonfiksi. Pembiasaan kegiatan literasi ini dilakukan dengan tujuan untuk meningkatkan kemampuan literasi membaca peserta didik. Banyak informasi-informasi yang akan didapat- 
kan oleh peserta didik dengan membaca. Dalam mentransformasikan sebuah informasi, kemampuan dalam memahami apa yang dibaca juga diperlukan. Apalagi untuk materi geometri yang sangat memerlukan kemampuan memahami informasi atau bacaan dengan benar. Tidak semua peserta didik dapat dengan mudah memahami bacaan. Terdapat hubungan positif antara minat membaca dan kemampuan dalam memahami bacaan (Astuti, Mumpuni, \& Pranoto, 2019). Hal ini dapat berarti bahwa dengan melihat minat membaca, kemampuan memahami bacaan dapat dideskripsikan. Minat membaca adalah kecenderungan hati untuk membaca sumber bacaan tertentu (Rahayu, 2016). Dengan adanya minat, peserta didik dapat mempunyai dorongan dari dalam diri untuk membaca. Minat membaca mempunyai hubungan yang signifikan dengan hasil belajar (Rahayu, 2016). Hasil belajar bersifat sangat luas, dimana di dalamnya juga terkandung pemahaman matematis. Salah satu standar yang dapat mendeskripsikan pemahaman matematis adalah kemampuan representasi matematis (NCTM, 2000). Hal ini dapat dikatakan bahwa minat membaca berpengaruh kepada kemampuan representasi matematis. Sumber lain mengatakan bahwa minat membaca yang tinggi akan memuat minat belajar tinggi pula (Ruslan \& Wibayanti, 2019).

Tujuan dari penelitian ini adalah untuk mengidetifikasi indikatorindikator mana saja yang dapat dikuasai oleh peserta didik yang mempunyai minat membaca di tingkat tinggi, sedang, dan rendah. Rumusan masalah yang diusung adalah indikator-indikator kemampuan representasi apa saja yang dapat dikuasai oleh peserta didik yang mempunyai minat membaca di tingkat tinggi, sedang, dan rendah pada materi geometri. Manfaat dari penelitian ini adalah dapat memberikan pengetahuan kepada pendidik untuk bisa memaksilkan kemampuan representasi secara efektif dan efisien berdasarkan tingkat minat membaca peserta didik.

\section{METODE PENELITIAN}

Penelitian ini merupakan penelitian kualitatif. Desain penelitian yaitu: (1) merancang instrumen penelitian yaitu berupa skala minat membaca, soal tes kemampuan representasi matematis; (2) memberikan skala minat membaca dan soal tes kemampuan representasi matematis kepada peserta didik; (3) memetakan hasil skala minat membaca pada kriteria rendah, sedang, dan tinggi kemudian memilih satu peserta didik untuk masing-masing diidentifikasi kemampuan representasi matematis; (4) wawancara mendalam mengenai kemampuan representasi matematis peserta didik yang mempunyai minat membaca rendah, sedang, dan tinggi.

Subjek penelitian adalah mahasiswa Jurusan Pendidikan Matematika Universitas Ivet. Prosedur pengumpulan data yang digunakan adalah skala, tes, dan wawancara. Instrumen dari penelitian ini yaitu skala minat membaca, soal tes kemampuan representasi matematis, dan lembar wawancara. Teknik analisis data dari penelitian ini mengadopsi teknik analisis data dari Miles dan Huberman, yaitu membuat catatan saat memeriksa lembar jawaban peserta didik serta saat melalukan wawancara, 
menyaring data yang diperoleh untuk menjawab rumusan masalah, mengidentifikasi pola dari hasil informasi yang telah disaring, menguraikan secara rinci kumpulan informasi.

\section{HASIL DAN PEMBAHASAN}

Indikator pertama dari kemampuan representasi matematis adalah menggunakan representasi untuk memodelkan serta menafsirkan fenomena fisik, sosial, dan matematika. Peserta didik yang mempunyai minat baca tinggi dapat merepresentasikan informasi di soal dalam bentuk gambar yang benar, sesuai skala ukuran, serta peletakan nama sudut juga benar. Peserta didik yang mempunyai minat baca tinggi bahkan dapat memberikan simbol-simbol sudut sehadap, simbol dua garis yang sejajar, bahkan mempunyai inisiatif untuk memisahkan segitiga menjadi dua buah segitiga yang sebangun. Hal ini tampak pada Gambar 1.

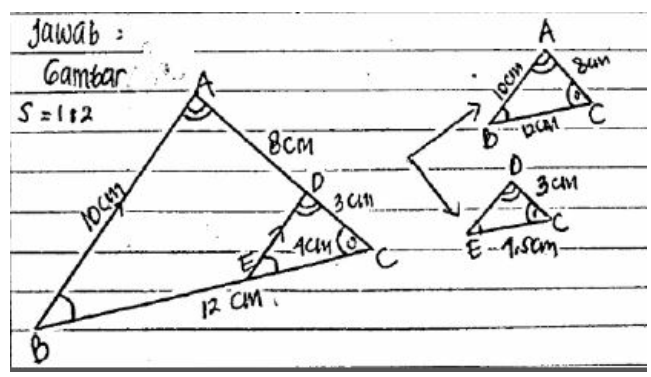

Gambar 1. Pemberian Simbol Pada Gambar Kelompok Atas

Peserta didik yang mempunyai minat membaca tingkat sedang dapat merepresentasikan informasi dalam bentuk gambar dengan benar. Peserta didik dapat menggambarkan sesuai skala ukuran dan peletakan nama sudut juga benar. Peserta didik mampu memberi simbol untuk sisi yang dicari, namun belum bisa memberikan simbol-simbol penting, contohnya simbol sejajar, simbol sudut sehadap. Hal ini dapat dilihat pada Gambar 2.

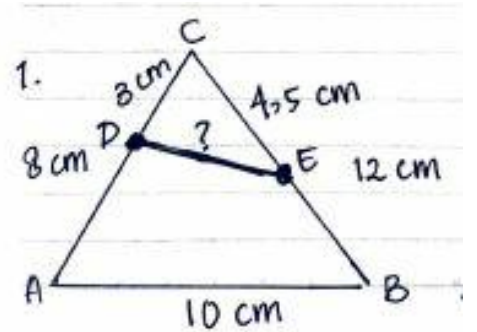

Gambar 2. Peenggambaran oleh Kelompok Sedang

Peserta didik yang mempunyai minat membaca rendah kurang dapat merepresentasikan informasi dalam bentuk gambar dengan benar, karena walaupun mampu menggambarkan bentuk bangun dan penamaan titik sudut dengan benar, namun belum bisa membuat panjang garis yang sesuai dengan skala ukuran. Hal ini tampak pada Gambar 3.

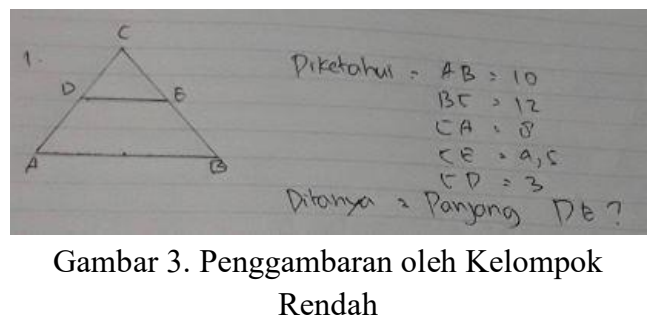

Peserta didik yang mempunyai minat membaca rendah kurang memiliki pengalaman dalam mengeksplorasi materi melalui kegiatan membaca, sehingga memiliki kekurangan dalam menemukan konsep sendiri dan mengaplikasikan konsep dalam bentuk representasi yang berbeda (Herdiman, 
Jayanti, Pertiwi, \& N, 2018). Hal ini juga dibahas oleh penelitian sebelumnya, bahwa manfaat dari minat membaca adalah bertambahnya pengalaman peserta didik (Siswati, 2010).

Indikator yang ke dua yaitu membuat dan menggunakan representasi untuk mengkomunikasikan ide-ide atau konsep matematika. Peserta didik yang mempunyai minat baca tinggi dapat menggunakan informasi yang diketahui di soal untuk dimasukkan ke konsep matematika. Peserta didik yang mempunyai kemampuan representasi matematis akan dapat memahami konsep yang melibatkan matematika (Lee \& Chen, 2015). Peserta didik yang mempunyai minat membaca tinggi maka akan lebih bersifat aktif secara fisik dan mental. Hal ini selaras dengan hasil penelitian sebelumnya yaitu kemampuan representasi matematis akan terbentuk pada peserta didik yang aktif secara fisik dan mental (Sulistyowaty, Kesumah, \& Priatna, 2019). Melalui kegiatan aktif yaitu membaca, peserta didik dapat menyimpan informasi lebih lama daripada informasi yang diperloleh melalui kegiatan melihat dan mendengar saja (Utami, Wibowo, \& Susanti, 2018). Peserta didik dengan tingkat membaca tinggi dapat memilih pasangan sudut yang sehadap seperti pada Gambar 4 .

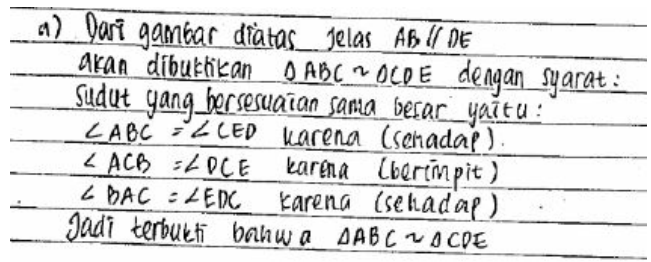

Gambar 4. Pemilihan Pasangan Sudut yang Sehadap
Peserta didik yang mempunyai minat baca tinggi juga bisa memilih sisisisi yang bersesuaian pada dua bangun segitiga seperti pada Gambar 5.

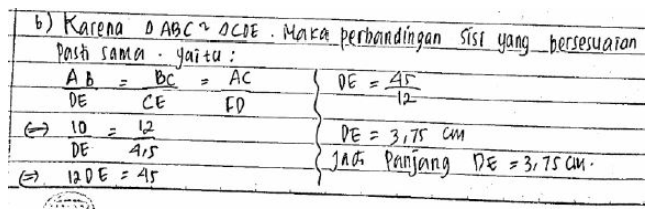

Gambar 5. Pemilihan Sisi-Sisi yang Bersesuaian

Peserta didik yang mempunyai minat baca tinggi juga bisa menentukan pasangan sisi yang sama panjang melalui definisi jajar genjang, tampak pada Gambar 6.

Mencafi panjang CB dan BE dengan definiss jajar genjang yang berbunyi dua pasang rusue yang masing - masing sama panjang dan sejajar dengan pasanganya, dan memiaki suaut yang masing = masing suma besas dengan

Jadi terbukk hah wa $C D=B E$ Tyaitu 4 an dan $D E=C B$ yaitu gom. $B E=4 \mathrm{~cm}$ dan $C B=\mathrm{gam}$

Gambar 6. Penentuan Pasangan Sisi yang Sama Panjang

Selain itu, peserta didik yang mempunyai minat baca tinggi bisa memasukkan panjang garis yang tepat pada Teorema Stewart, ditunjukkan pada Gambar 7.

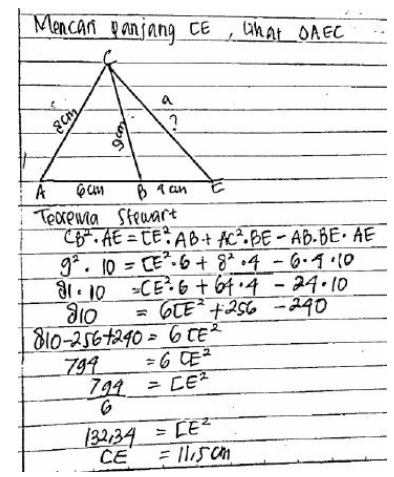

Gambar 7. Pemasukkan Panjang Garis yang Tepat pada teorema Stewart Stewart oleh Peserta Didik yang Mempunyai Minat Membaca Tingkat Tinggi 
Peserta didik yang mempunyai minat membaca tingkat sedang mampu menggunakan informasi yang diketahui untuk dapat menggunakannya di konsep matematika. Peserta didik dapat menunjukkan sisi-sisi yang bersesuaian dan memasukkan ke perbandingan sisisisi yang bersesuaian sehingga dapat menentukan kesebangunan dua buah segitiga tampak pada pada Gambar 8 .

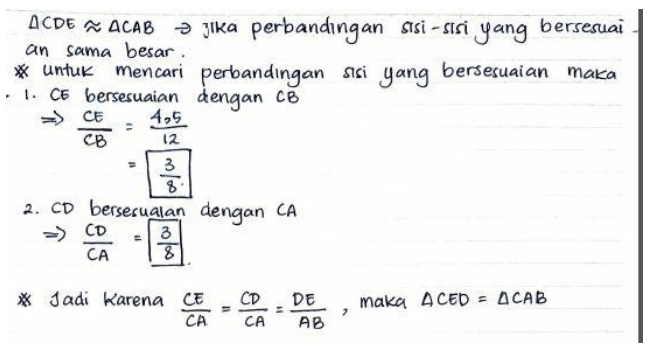

Gambar 8. Pembuktian Kesebangunan Dua Buah Segitiga

Peserta didik yang mempunyai minat membaca tingkat sedang dapat memasukkan garis yang sesuai dengan dengan Teorema Stewart. Hal ini tampak pada Gambar 9.

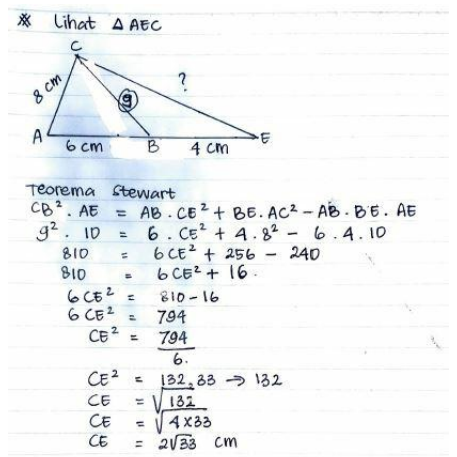

Gambar 9. Pemasukkan Panjang Garis yang Tepat pada teorema Stewart oleh Peserta Didik yang Mempunyai Minat Membaca Tingkat Sedang

Peserta didik yang mempunyai minat membaca rendah tidak bisa memasukkan informasi yang diketahui pada konsep matematika. Hal ini terlihat dari jawaban peserta didik pada Gambar 10. Pada Gambar 10 terlihat bahwa peserta didik belum bisa memasukkan garis yang sesuai pada teorema Stewart. Kesalahan mulai dari baris pertama yang diberi lingkaran berwarna merah.

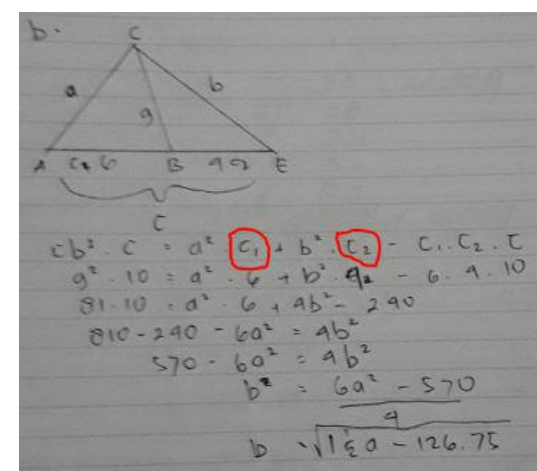

Gambar 10. Pemasukkan Panjang Garis yang Salah pada Teorema Stewart oleh Stewart oleh

Peserta Didik yang Mempunyai Minat Membaca Tingkat Rendah

Indikator kemampuan representasi matematis yang ke tiga yaitu memilih, menerapkan, dan menerjemahkan representasi matematika untuk memecahkan masalah. Peserta didik yang mempunyai minat baca tinggi dapat mencari panjang garis menggunakan konsep kesebangunan dua buah segitiga. Peserta didik yang mempunyai minat baca tinggi juga dapat menentukan panjang garis menggunakan Teorema Stewart. Pemilihan Teorema Stewart dari sekian banyak teorema yang ada, ini membuktikan bahwa peserta didik yang mempunyai minat baca tinggi dapat memilih, menerapkan dan menerjemahkan representasi matematis untuk memecahkan masalah. Peserta didik yang dapat memecahkan masalah berarti dapat memahami soal dengan baik. Hal 
ini didukung oleh penelitian sebelumnya yaitu minat membaca mempunyai hubungan yang linier dengan kemampuan memahami teks (Astuti et al., 2019). Sama halnya dengan peserta didik yang mempunyai minat baca tinggi, peserta didik yang mempunyai minat membaca tingkat sedang juga memiliki kemampuan untuk memilih, menerapkan, menerjemahkan representasi matematis untuk memecahkan masalah. Hal ini terlihat pada alur penyelesaian permasalahan yang benar dan runtut sehingga solusi dari permasalahan tersebut dapat diperoleh. Peserta didik yang mempunyai minat membaca rendah mengalami kesulitan dalam menyelesaikan permasalahan, karena peserta didik sulit dalam pemilihan dan penggunaan informasi ke dalam konsep matematika, sehingga menyebabkan solusi permasalahan tidak bisa didapatkan. Hal ini menggambarkan bahwa peserta didik yang mempunyai minat membaca tingkat rendah tidak mempunyai kemampuan dalam memilih, menerapkan, dan menerjemahkan representasi matematis untuk memecahkan masalah.

\section{PENUTUP}

Simpulan dari penelitian ini adalah: (1) kemampuan representasi matematis dalam menggunakan representasi untuk memodelkan serta menafsirkan fenomena fisik, sosial, dan matematika dimiliki oleh peserta didik yang mempunyai minat membaca tingkat tinggi dan sedang, namun kurang dikuasai oleh peserta didik yang mempunyai minat membaca tingkat rendah; (2) kemampuan representasi matematis dalam membuat dan menggunakan representasi untuk mengkomunikasikan ide-ide atau konsep matematika dimiliki oleh peserta didik yang mempunyai minat membaca tingkat tinggi dan sedang, dan tidak dimiliki oleh peserta didik yang mempunyai minat membaca rendah; (3) kemampuan representasi matematis dalam memilih, menerapkan, dan menerjemahkan representasi matematika untuk memecahkan masalah dimiliki oleh peserta didik yang mempunyai minat membaca tingkat tinggi dan sedang, dan tidak dimiliki oleh peserta didik yang mempunyai minat membaca rendah. Hasil penelitian ini dapat digunakan untuk memetakan kemampuan representasi matematis siswa berdasarkan minat membacanya, sehingga pendidik dapat menentukan indikator kemampuan representasi matematis yang perlu lebih ditingkatkan berdasarkan tingkatan minat membaca siswa. Pendidik dapat memaksimalkan kemampuan representasi siswa dengan meningkatkan minat membaca melalui kegiatan pembiasaan-pembiasaan membaca di sekolah.

\section{DAFTAR PUSTAKA}

Astuti, P., Mumpuni, A., \& Pranoto, B. A. (2019). Pengaruh Minat Dan Kemampuan Membaca Peserta Didik Dalam Memahami Teks Bacaan. Jurnal kontekstual, 01(1), 26-32.

Graciella, M., \& Suwangsih, E. (2016). Penerapan Pendekatan Matematika Realistik Untuk Meningkatkan Kemampuan Representasi Matematis Siswa. Metodik Didaktik, 10(2), 27-36. https://doi. org/10.17509/md.v10i2.3180 
Herdiman, I., Jayanti, K., Pertiwi, K. A., \& N, R. N. (2018). Kemampuan Representasi Matematis Siswa SMP pada Materi Kekongruenan dan Kesebangunan. Jurnal Elemen, 4(2), 216-229. https://doi.org/10.29408/jel.v4i2.5 39

Lee, C. Y., \& Chen, M. J. (2015). Effects of Polya questioning instruction for geometry reasoning in junior high school. Eurasia Journal of Mathematics, Science and Technology Education, 11(6), 1547-1561.

https://doi.org/10.12973/eurasia.2 015.1419a

Mainali, B. R. (2021). Representation in Teaching and Learning Mathematics To cite this article: Journal of Education in Mathematics, Science, and Technology (IJEMST), 9(1), 1-21. https://doi.org/10.46328/ijemst.11 11

Miladiah, A., Nurhaida, \& Karimah, N. I. (2020). Analisis Kemampuan Representasi Matematis Siswa dalam Menyelesaikan Soal Cerita Program Linear. JRPMS (Jurnal Riset Pembelajaran Matematika Sekolah), 4(2), 9-14. https://doi.org/10.31958/jt.v22i1.1 226

NCTM. (2000). Principles and Standards for School Mathematics. America: The National Council of Teachers of Mathematics, Inc.

Rahayu, L. T. I. (2016). Hubungan Minat Membaca dan Motivasi Belajar Dengan Hasil Belajar Materi Menulis Karangan Pada Warga Belajar Kejar Paket C Di PKBM Al-Firdauz Kabupaten Serang. Jurnal Eksistensi Pendidikan Luar
Sekolah (E-Plus), 1(2), 188-201.

Rahmadian, N., Mulyono, \& Isnarto. (2019). Kemampuan Representasi Matematis dalam Model Pembelajaran Somatic, Auditory, Visualization, Intellectually (SAVI). PRISMA, Prosiding Seminar Nasional Matematika, 2, 287-292. Retrieved from https://journal.unnes.ac.id/sju/inde x.php/prisma/article/view/28940

Ruslan, \& Wibayanti, S. H. (2019). Pentingnya Meningkatkan Minat Baca Siswa. Prosiding Seminar Nasional Pendidikan Program Pascasarjana Universitas PGRI Palembang, 767-775. Retrieved from www.perpusnas.go.id

Sabirin, M. (2014). Representasi dalam Pembelajaran Matematika. Jurnal Pendidikan Matematika, 1(2), 3344.

https://doi.org/10.18592/jpm.v1i2. 49

Siswati. (2010). Minat Membaca Pada Mahasiswa. Jurnal Studi Deskripsif, 8(2).

Sulistyowaty, R. K., Kesumah, Y. S., \& Priatna, B. A. (2019). Peningkatan Kemampuan Representasi Matematis Melalui Pembelajaran Collaborative Problem Solving. Jurnal Pendidikan Matematika, 13(2), 153-162. https://doi.org/10.22342/jpm.13.2. 6829.153-162

Utami, R. D., Wibowo, D. C., \& Susanti, Y. (2018). Analisis Minat Membaca Siswa pada Kelas Tinggi di Sekolah Dasar Negeri 01 Belitang. Jurnal Pendidikan Dasar PerKhasa, 4(1), 179-188.

Widakdo, W. A. (2017). Mathematical Representation Ability by Using Project Based Learning on the 
Topic of Statistics Mathematical Representation Ability by Using Project Based Learning on the Topic of Statistics. Journal of Physics: Conf. Series, 895, 1-7.

Wilkinson, L. C., Bailey, A. L., \& Maher, C. A. (2018). Students , Mathematical Reasoning , Communication, and Language Representations: A VideoNarrative Analysis. Ecnu Review of Education, 1(3), 1-22. https://doi.org/10.30926/ecnuroe2 018010301

Yuniawatika. (2011). Penerapan Pembelajaran Maematika dengan Strategi REACT untuk Meningkatkan Kemampuan Koneksi dan Representasi Matematik Siswa Sekolah Dasar (Studi Kuasi Eksperimen di Kelas V Sekolah Dasar Kota Cimahi). Metodik Didaktik, Edisi Khus, 105-119. 